DAKWATUNA

Jurnal Dakwah dan Komunikasi Islam

Volume 6, Nomor 2, Agustus 2020

\title{
Simbolisasi Dakwah HTI pada Al-Ra>yah dan Al-Liwa (Analilis Semiologi Roland Barthes)
}

\author{
Muhyiddin Sholeh \\ Institut Agama Islam Syarifuddin Lumajang, Indonesia \\ Email: muhyiddinsholeh@gmail.com
}

\author{
Achmad Farid \\ Institut Agama Islam Syarifuddin Lumajang, Indonesia \\ Email: ac.faried@gmail.com
}

\begin{abstract}
This paper will focus on reading al-ra>yah and al-liwa> signs. In its history, the tugging of al-ra>yah and al-liwa> claims as a symbol of the legal identity of the Messenger of Allah has always been a contentious reality. Clearly occupying alra> yah and al-liwa> as historical reality and as a result of reading history for later adoption in certain ideologies is very important. The reading of signs in the form of text and visual images to find out the meaning of the construction of al-ra>yah and al-liwa> will offer problem solving for the problems of the people who are being loved by symbolic trends in religious life. Qualitative research with the semiology approach of Roland Barthes with denotative, connotative and mythical systematics. The results of this study provide an overview of the different variations on the reading of the signs that exist in al-ra> yah and alliwa both as texts and religious symbols.
\end{abstract}

Keywords: al-ra>yah and al-liwa>, symbol, semiotics

\begin{abstract}
Abstrak
Dalam tulisan ini akan memfokuskan diri pada pembacaan akan tanda-tanda alra>yah dan al-liwa>. Dalam sejarahnya, tarik ulur klaim al-ra>yah dan al-liwa> sebagai simbol identitas yang legal dari Rasulullah selalu menjadi realitas yang diperdebatkan. Mendudukan secara jelas al-ra>yah dan al-liwa> sebagai realitas historis dan sebagai hasil pembacaan sejarah untuk kemudian diadopsi dalam idiologi tertentu menjadi hal yang sangat penting. Pembacaan tanda-tanda baik berupa teks maupun visual gambar untuk mengetahui makna konstruksi alra>yah dan al-liwa > akan menawarkan problem solving atas permasalahan umat yang sedang digandrungi tren simbolik dalam kehidupan beragama. Penelitian kualitatif dengan pendekatan semiologi Roland Barthes dangan sistematika denotatif, konotatif dan mitos. Hasil penelitian ini memberi gambaran tentang ragam berbeda atas pembacaan tanda-tanda yang ada pada al-ra >yah dan al-liwa baik sebagai teks maupun simbol keagamaan.
\end{abstract}

Kata Kunci: al-ra>yah dan al-liwa>, simbol, semiologi. 


\section{PENDAHULUAN}

Bendera atau panji Rasulullah dikenal dengan istilah al-ra>yah dan alliwa > dimana ditengah-tengahnya tertulis lafal tauhid. Bendera berlafal tauhid sebagai sebuah identitas dan simbol tercatat dipakai oleh Negara Arab Saudi, ISIS, dan Hizbut Tahrir. Hal ini bisa dimaklumi disebabkan tingginya derajat kalimat tauhid bagi umat Islam. Menariknya, konotasi makna yang terkandung dalam bendera berlafal tauhid harus digali sedalam mungkin.

Bendera berlafal tauhid sebagai sebuah simbol muncul dari proses pemaknaan atas teks-teks keagamaan. Dalam membaca teks-teks keagamaan, pencarian makna terhadap suatu simbol dan tanda, meskipun dalam satu kasus yang sama, akan menghasilkan penafsiran berbeda dengan bergantinya konteks ruang dan waktu. Termasuk di dalamnya cara memahami al-ra>yah dan al- liwa> sebagai entitas sejarah Nabi dan sebagai identitas organisasi yang mempunyai idiologi tertentu.

Berbicara tentang simbol, manusia tak kan pernah sepi dari simbolsimbol tertentu. Simbol selalu memiliki makna tersembunyi atau pesan-pesan yang bisa dikaji melalui ilmu semiotik ${ }^{1}$. Simbol bisa merujuk pada kearifan lokal maupun identitas individu ${ }^{2}$. Di sisi lain, simbol menjadi tanda eksistensi pergerakan seseorang maupun kelompok. Tanpa sadar simbol terinternalisasi dalam kehidupan seseorang sehingga ia menjadi identitas. Jika suatu simbol dilecehkan, maka konflik pun tidak bisa dihindari. Sebagai contoh, insiden pembakaran bendera PDIP oleh massa di depan gedung DPR pada tanggal 24 Juni 2020 kemarin menjadi bukti nyata betapa suatu simbol menjadi sangat urgen. 3

\footnotetext{
1 Bambang Subahri. 2020. Pesan Semiotik Pada Tradisi Makan Tabheg Di Pondok Pesantren. Dakwatuna: Jurnal Dakwah dan Komunikasi Islam 6(1), 88-103.

${ }^{2}$ Bambang Subahri. (2018). Pesan Simbolik Tradisi Sandingan Pada Masyarakat Pandalungan Di Desa Jenggrong Kecamatan Ranuyoso Kabupaten Lumajang. Dakwatuna: Jurnal Dakwah dan Komunikasi Islam, 4(2), 292-305.

$3 \quad$ Lihat, https://www.cnnindonesia.com/nasional/20200629181108-20-518752/responspembakaran-bendera-kader-pdip-merahkan-surabaya, diakses tanggal 1 Juli 2020
} 
Seperti insiden pembakaran bendera PDIP, beberapa tahun yang lalu terjadi hal yang serupa. Melibatkan antara BANSER dan $\mathrm{HTI}$, tepatnya pada peringatan Hari Santri Nasional (22 Oktober 2018) di Kecamatan Limbangan, Kabupaten Garut, Jawa Barat. Terjadi peristiwa pembakaran bendera tauhid, ini menjadi viral setelah video berdurasi 2,04 menit beredar secara bebas lewat jejaring sosial. ${ }^{4}$

Pada awalnya, acara dilaksanakan untuk memperingati hari santri diikuti oleh berbagai kalangan. Di dalam perjanjiannya, santri dilarang membawa bendera selain merah putih. Namun, di lapangan ternyata ada yang mengibarkan bendera tauhid. Seketika, BANSER langsung mengamankan bendera tersebut dan beberapa oknum malah membakar sebuah bendera hitam yang bertuliskan lafal tauhid di dalamnya. Mereka mengklaim bendera tersebut adalah milik ormas yang telah dibubarkan oleh negara dikarenakan bertentangan dengan Pancasila sebagai dasar negara.

Berbagai respon pro dan kontra menanggapi kasus ini. Ketua GP Ansor, Yaqut Cholil Qoumas sendiri melakukan pembelaan terhadap anggota yang melakukannya. Mereka melakukan pembelaan dengan cara konsisten menyatakan bahwa bendera yang dibakar adalah bendera HTI bukan bendera Rasulullah. 5 Pembakaran yang dilakukanpun bukan bermaksud menghina dan menistakan simbol-simbol agama, justru menghormati simbol-simbol tersebut sebagaimana bolehnya membakar sobekan mushaf al-qur'an yang tercecer. ${ }^{6}$

Respon berbeda ditampilkan Ismail Yusanto (Eks juru bicara HTI) yang tidak sepakat dengan pernyataan Yaqut. Menurutnya, bendera yang dibakar bukanlah milik organisasi yang telah dinyatakan terlarang oleh pemerintah,

\footnotetext{
4 Bagaimana pembakaran 'bendera HTI' itu jadi 'pembakaran bendera tauhid'? dalam : https://www.bbc.com/indonesia/indonesia-45951832, diakses 1 Juli 2020

5 Jika klaim bahwa bendera HTI dan ISIS adalah panji Rasulullah, maka mengapa HTI tidak mau mengibarkan bendera ISIS, atau sebaliknya ?. logika ini juga dipakai oleh Nadirsyah Husein dalam catatannya, lihat https://nadirhosen.net/kehidupan/negara/penjelasan-soal-hadits-nabidan-bendera-khilafah-hti-isis, diakses 1 Juli 2020

${ }^{6}$ ibid
} 
Melainkan bendera Rasulullah yang harus dihormati dan dijaga.7 Akibatnya, insiden pembakaran tersebut merupukan pelecehan dan penghinaan. Dan para pelaku dicap sebagai penista agama. Sebagai imbasnya, maka terjadilah demodemo aksi bela Tauhid.

\section{METODE PENELITIAN}

Metode yang dipakai dalam jurnal ini adalah penelitian kepustakaan (library Research) dengan fokus pembahasan yaitu al-rasyah dan al- Liwa> diteropong melalui ilmu semiologi.

Mengenai batasan masalah dalam penelitian ini kita akan tentukan objek matrial dan objek formal. Objek matrial dari tinjuan semiologi adalah teks dan visual dari bendera al-ra>yah dan al- liwa>. Untuk objek formal dari semiologi adalah penggalian makna terhadap tanda-tanda dalam visual al-ra>yah dan alLiwa>.

Al-Ra>yah dan al-liwa> sebagai tanda dan simbol akan menarik jika dilihat dari tinjauan semiologi Roland Barthes. Menurut Barthes tanda konotatif tidak sekedar memiliki makna tambahan, namun juga berisi tanda denotatif yang melandasi keberadaannya. Bagi Barthes, konotasi identik dengan operasi ideologi yang disebutnya sebagai mitos, dan berfungsi untuk mengungkapkan dan memberikan pembenaran bagi nilai-nilai dominan yang berlaku dalam suatu periode tertentu. Dalam mitos terdapat pola tiga dimensi, yaitu: penanda, petanda dan tanda, namun sebagai suatu sistem yang unik mitos dibangun oleh suatu rantai pemaknaan yang telah ada sebelumnya atau, dengan lain kata mitos adalah suatu sistem pemaknaan tataran kedua.

7 Lihat, https://news.detik.com/berita/d-4269180/ismail-yusanto-yang-dibakar-banser-bukanbendera-hti, diakses 1 Juli 2020 


\section{PEMBAHASAN}

\section{Pengertian Al-ra>yah dan al-liwa}

Secara bahasa sinonim al-ra>yah adalah al-'alam (bendera), jamaknya ialah raya>t, dan dalam pasal lawiya dinyatakan, al-liwa> adalah al-'alam (bendera), dan jamaknya ialah alwiyah.Al-ra>yah dan al-liwa> sama-sama memiliki arti bendera. Sedangkan pengertian bendera adalah sepotong kain yang berbentuk segi empat atau segitiga, biasanya diikatkan pada tiang dan dipergunakan sebagai lambang negara, perkumpulan, tanda atau panji-panji. ${ }^{8}$ Sehingga bendera kebangsaan ialah bendera yang dipakai sebagai tanda suatu negara. 9

Dalam sejarahnya, Nabi Muhammad menggunakan Al-ra>yah dan alliwa > sebagaimana dalam hadits Ibn Abba>s, Teks Hasits berbunyi :

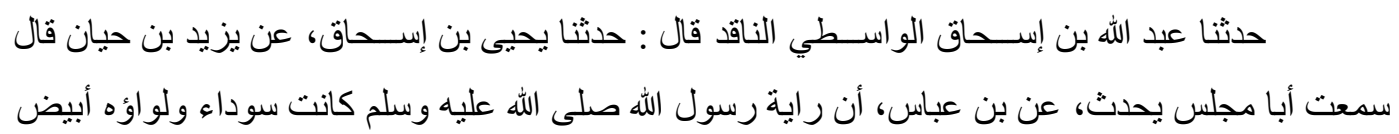

Telah menceritakan kepada kami 'Abd Allah bin Isha>q al-Wa<sitialNaqid berkata, telah menceritakan kepada kami Yah\{yabin Ish\{a<q, dari Yazi>d bin $\mathrm{H}\{$ ayya $>\mathrm{n}$ berkata, saya telah mendengar Abu>Mijlaz mengatakan, dari Ibn Abba>s, bahwa al-ra>yah Rasulullah SAW berwarna hitam dan al-liwa>-nya berwarna putih. ${ }^{10}$

Adapun ditengah bendera ( charge ) yang digunakan Nabi Muhammad tertulis kalimat sahadat yaitu la>ila>h illa> Alla>h Muh\{ammad rasu>| Alla>h yang artinya tiada Tuhan selain Allah Muhammad utusan Allah. Hal itu terekam dalam hadis yang disampaikan Abu Hurairah dan Ibnu Abbas, "Liwa Nabi Muhammad SAW tertulis la>ila>h illa $>$ Alla $>$ h Muh\{ammad rasu>l Alla $>h$ "

\footnotetext{
${ }^{8}$ Pusat Bahasa Departemen Pendidikan Nasional, Kamus Bahasa Indonesia (Jakarta: Pusat bahasa, 2008), 174.

9 Ibid

${ }^{10}$ Ibn Ma>jah, Sunan Ibn Ma>jah, (tk : Da>r Ihya>'al-Kutub al-'Arabiyyah, tt ), 941
} 
Bendera secara umum merupakan gambaran dari sebuah simbol yang dapat mengekspresikan dan merepresentasikan emotional dari kelompok yang sama. Hal tersebut seiringan dengan sifat nasionalisme yang mampu membuat suatu negara atau bangsa untuk memiliki kekuatan dan kegigihan sentimen dan identitas nasional. Sejatinya, pada zaman sekarang bendera mempunyai banyak fungsi. Salah satunya, bendera digunakan untuk membangkitkan emosional dari identitas sebuah kelompok, terlebih bendera menjadi identitas pembeda dengan kelompok yang lainnya. Oleh karena itu, bendera merupakan simbol yang melegitimasikan tiap individu untuk mengekspresikan keanggotannya pada kelompoknya, sehingga menguatkan solidaritas di antara perseorangan dalam kelompok tersebut. ${ }^{11}$

Visual al-ra>yah dan al-liwa> pada masa Nabi Muhammad sesuai informasi hadits-hadits meliputi ground, charge, shape,dan fungsi.

Al-Hujaili mengatakan bahan dasar dari bendera, yaitu al-namirah atau kain wool yang bermotif garis-garis putih. ${ }^{12}$ Bahkan, menurut lb nu Hisyam, warna bendera yang digunakan dalam perang Khaibar adalah putih. ${ }^{13} \mathrm{Hal}$ ini di amini oleh Al-Hujaili serta menyimpulkan bahwa bendera Nabi terdapat unsur warna putih, karena orang yang melihat panji itu dari jarak dekat menyatakan bahwa panji itu berwarna putih. ${ }^{14}$

Namun yang mencengangkan, rupanya ada hadits yang menyatakan ra<yah Nabi Muhammad berwarna kuning. Hadits ini disampaikan oleh Abu Dawud yang berbunyi :



${ }^{11}$ Elie Podeh, "The Symbolism of the Arab Flag in Modern Arab States: Between Commonality and Uniqueness", Nations and Nationalism, Hebrew University of Jerussalem, 17 (2), 2011, 420.

12 Abdullah bin Muhammad bin Sa'ad al-Hujaili, Al-'Alamu al-Nabawiy al-Shari<f wa Tat\}bi<qotuhu< al-Qodi<matu wal Mu'as\{orotu (Madinah al- Munawarah: Maktabatah al-'Ulu<m wa al-H\{ikam , 2002),, 68.

${ }^{13}$ Abu Muhammad Abdul Malik bin Hisyam al-Muafiri, Sirah Nabawiyah Ibnu Hisyam, Jilid 2, Terj. Fadhli Bahri (Jakarta: Darul Falah, cetakan ke-7, 2008), 304.

${ }^{14}$ Abdullah bin Muhammad bin Sa'ad al-Hujaili, Al-'Alamu al-Nabawiy al-Shari<f ..., 68. 
Telah menceritakan kepada 'Uqbah bin Mukram, telah menceritakan kepada kami Salm bin Qutaybah al-Sha'iri, dari Shu'bah, dari Simak, dari seorang lakilaki dari kaumnya dari (orang lain di antara mereka), ia berkata, aku melihat bendera Rasulullah SAW berwarna kuning. ${ }^{15}$

Menanggapi hadits ini, analisa al-Hujaili mengatakan, seseorang yang melihat al-ra<yah Nabi setelah peperangan akan menyatakan berwarna kuning karena panji tersebut telah berdebu dan melihatnya dari jauh. ${ }^{16}$

Sehingga sampai di sini bisa kita simpulkan sementara bahwa ground alra>yah berwarna hitam sedangkan al-liwa> memiliki ground putih.

Adapun Charge atau tulisan ditengah bendera yang digunakan Nabi Muhammad berupa kalimat syahadat yaitu la>ila>h illa $>$ Alla $>$ h Muh\{ammad rasu>l Alla>h yang artinya tiada Tuhan selain Allah Muhammad utusan Allah.Pencantuman kalimat persaksian itu terekam dalam hadis yang disampaikan Abu Hurairah dan Ibnu Abbas, "Liwa Nabi Muhammad SAW tertulis la>ila>h illa> Alla>h Muh\{ammad rasu>l Alla>h" Mahmud Abbas memperkirakan bahan yang digunakan untuk menulis adalah arang hitam atau jelaga yang dicampur dengan getah pohon. Khat yang dipakai adalah Makkiy dan Madaniy. ${ }^{17}$

Adapun Bentuk (shape) bendera Rasulullah adalah segiempat. Hal ini sebagaimana hadis yang disampaikan oleh Barra' bin al-A><zib yang berbunyi : حدثنا أحمد بن منيع، قال : حدثنا يحيى بن زكريا بن أبي زائدة، قال : حدثنا أبو يعقوب الثقفي ،

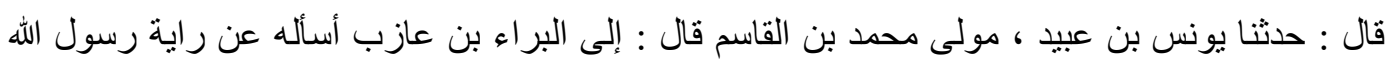

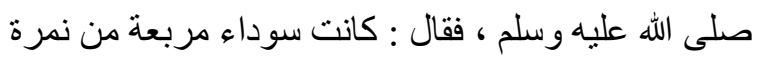

Telah menceritakan kepada kami Ah\}mad bin Mani>‘ berkata, telah menceritakan kepada kami Yahya> bin Zakariyya> bin Abi> Za>'idah berkata, menceritakan kepada kami Abu> Ya'qu>b al-Thaqafi> berkata, menceritakan

\footnotetext{
${ }^{15}$ Abu Dawud Sulayman bin al-Ash'ath bin Ishaq bin Bashir bin Shaddad bin 'Amr al-Azdi alSijistani, Sunan Abi Dawud, Muhaqqiq: Muhammad Muhy al-Din 'Abd al-Hamid, Vol. 3, Nomor Hadis 2593 (Beirut: al-Maktabah al-'Asriyyah, tt), 32.

${ }^{16}$ Abdullah bin Muhammad bin Sa'ad al-Hujaili, Al-'Alamu al-Nabawiy al-Shari<f ....,, 68.

17 Ibid, $65-67$
} 
kepada kami Yunus bin 'Ubayd, mantan budak Muh\}ammad bin al- Qa>sim, ia berkata, Muh\}ammad bin al-Qa>sim mengutusku kepada al-Barra' bin ‘A<zib untuk bertanya tentang ra>yah (bendera) Rasulullah shalla> Alla>h 'Alayh wa salam. Ia lalu menjawab, "bendera beliau berwarna hitam, bentuknya persegi empat dan terbuat dari kain wool yang bergaris". ${ }^{18}$

Adapun fungsi dari al-ra>yah dan al-liwa< banyak dipergunakan terutama dalam peperangan. Selain itu, ketika memimpin rombongan pasukan dalam gerakan damai, misalnya pada fathul Makkah, Nabi Muhammad juga membawa bendera tersebut. Demikian pula, bendera Islam juga dipakai ketika utusan Nabi Muhammad bertugas melaksanakan hukuman. Dan tidak pernah digunakan sebagai simbol identitas islam sebagai negara.

\section{Simbolisasi Dakwah HTI pada Al-ra>yah dan al-liwa>}

Kata "simbol" berasal dari kata Yunani yaitu sumballeo atau sumballein yang berarti berunding, berdebat, merenungkan, bertemu/ membantu. Kajian simbolisme sering disertai dengan membedakan antara simbol dan tanda. Antara tanda dan simbol mempunyai hubunga yang erat. Perbedaan tanda dan simbol menurut Saliba ialah bahwa tanda secara umum memberikan informasi tentang suatu keadaan dari kejadian, hal, atau hubungan, seperti: lampu lalu lintas memberikan informasi khusus. Simbol adalah sarana atau pembawa buah pikiran atau makna. Simbol mengandung suatu pengertian yang tidak mengandung informasi langsung. ${ }^{19}$

Manusia erat kaitanya dengan simbol-simbol dalam menjalankan kehidupan, bahkan simbol-simbol yang dipakai terus dijaga dan diwariskan kepada anak cucu mereka. ${ }^{20}$ Makna simbol sendiri sangat luas. Contohnya dalam melakukan aktifitas keberagamaan. Dalam suatu agama tentunya

\footnotetext{
${ }^{18}$ Muhammad bin 'Isa bin Sawrah bin Mu>sa al-Tirmidhi, Sunan al-Tirmidhi, Muhaqqiq: Bashar'Iwad Ma'ruf, vol. 3, No. Hadis 1680 (Beirut: Dar al-Gharb al-Islami, 1998), 248.

${ }^{19}$ Jhon A. Saliba, 'Homo Religiosus' in Mircea Elinde,( E. J. Brill : Leiden. 1976.), 83

${ }^{20}$ Ibnu Rachman, "Simbolisme Agama dalam Politik Islam", Jurnal Filsafat, Vol. 33, No. 1, (April, 2003), 95.
} 
mempunyai simbol tersendiri dengan makna yang mereka pahami dan mereka anut, bisa dari simbol tempat beragama maupun simbol dari agama itu sendiri. Misalnya agama Islam yang memiliki simbol dalam bentuk bulan dan bintang ataupun masjid, agama Kristen memiliki simbol dalam agamanya yaitu dalam bentuk salib.

Dalam bahasa Cassirer, manusia merupakan animal symbolicum. Manusia hidup dengan simbol, baik dalam bahasa, seni, mite atau religi. Pemahaman akan simbol merupakan pemahaman akan proses kultural pertumbuhan dan perkembangan pengetahuan manusia. Simbol merepresentasikan suatu makna yang bisa didefinisikan artinya ${ }^{21}$. Representasi itu bisa berada di entitas yang lain, semisal karya seni maupun benda lain yang tidak menyatu dengan entitas originalnya ${ }^{22}$.

Dalam kehidupan keberagamaan, seringkali penganut agama tertentu mencoba menyimbolkan norma-norma dan teks-teks agama yang mereka pahami. Karena bentuk visual yang real jauh lebih gampang dicerna otak, dari pada sebuah pemahaman yang abstrak. Dalam perkembangannya, kelompokkelompok agama yang memiliki pemahaman tekstualis akan lebih banyak menyimbolisasikan teks-teks agama meski tidak semuanya benar. Salah satu kelompok agama yang gemar menyimbolkan teks-teks agama adalah Hizbut Tahrir.

Di Indonesia, Hizbut Tahrir mempunyai nama khusus yaitu HTI atau Hizbut Tahrir Indonesia. Sebagaimana Hizbut Tahrir pada umumnya, HTI juga sama dalam dakwahnya. Dakwah sendiri merupakan upaya mengajak pada jalan kebenaran yang diklaim oleh pendakwah. Dakwah mesti mengikuti pola perkembangan zaman dan dengan metode yang baik agar diterima

${ }^{21}$ Rio Febriannur Rachman. (2015). Representasi Muslim Dalam Film-Film Produksi Hollywood (Analisis Dua Film Kathryn Bigelow: The Hurt Locker Dan Zero Dark Thirty) (Master Thesis, Universitas Airlangga).

22 Rio Febriannur Rachman. (2016). Representasi Islam di Film Amerika Serikat. Dakwatuna: Jurnal Dakwah dan Komunikasi Islam, 2(2), 1-12. 
masyarakat ${ }^{23}$. Metode dakwah mengalami perkembangan dari masa ke masa, demi menguatkan strategi pendakwah di era kekinian²4.

Hizbut Tahrir mempunyai ciri khas dalam dakwahnya. Salah satu ciri khas yang dikenal banyak kalangan adalah penggunaan bendera berlafal tauhid sebagai identitas kelompok, meskipun mereka sendiri mengklaim bahwa HTI tidak punya bendera, sedang bendera yang mereka pakai - berdasar klaim mereka- adalah bendera Rasulullah yang dikenal dengan al-ra>yah dan al-liwa>.

Tentu dengan dakwah yang seperti ini, HTI dengan mudahnya mendapatkan simpatisan dan jama'ah. Karena para simpatisan dan jama'ah percaya, HTI lebih dekat dengan Rasulullah dan cita-cita beliau. Buktinya, bendera HTI dan panji rasul sama. Hal yang tidak ditemukan pada kelompok lain dalam Islam.

Melihat Al-ra>yah dan al-liwa> sebagai simbol, Deni Junaidi mengaklasifikasi dan membedakan antara al-ra>yah dan al-liwa> sebagai simbol Islam dengan simbol khilafah. ${ }^{25}$ Sebagai simbol Islam, al-ra>yah dan al-liwa> tidak terlepas dari sejarah penggunaannya sebagai bendera perang Rasulullah SAW. Sedangkan sebagai simbol khilafah, al-ra>yah dan al-liwa> mempunyai kapasitas untuk dikaitkan dengan ide tertentu. Nilai simbolis bendera tersebut terletak pada sikap yang berbeda dari kalangan umat Islam. Ada yang menganggapnya sebagai repsentasi dari panji Rasulullah ada pula yang menganggapnya sebagai simbol organisasi tertentu.

Kalimat la>ila>h illa> Alla>h Muh\{ammad rasu>l Alla>h merupakan identitas yang membedakan antara Islam dan kafir. Di dalam Islam dimungkinkan ada perbedaan (khila<fiyah) dalam tatacara ibadah, namun

\footnotetext{
${ }^{23}$ M. Darwis. (2016). Teologi Dakwah Dalam Kajian Paradigmatik. Dakwatuna: Jurnal Dakwah dan Komunikasi Islam, 2(1), 85-106.

${ }^{24}$ M. Darwis. (2019). Rejuvenasi Paradigma Dakwah Di Era 4.0. Dakwatuna: Jurnal Dakwah dan Komunikasi Islam, 5(1), 58-67.

${ }^{25}$ Deni Junaedi, "Bendera di Hizbut Tahrir Indonesia Daerah Istimewa Yogyakarta "Kajian Konteks Sejarah, Konteks Budaya, dan Estetika Semiotis", Tesis, ( Universitas Gadjah Mada, Yogyakarta ), $237-239$
} 
perbedaan syahadat tidak dimungkinkan; dengan kata lain tidak terdapat perbedaan dalam tataran akidah. Dengan demikian, bendera yang bertuliskan sahadat terkait erat dengan keislaman.

Nilai ikonis pada al-rasyah dan al-liwas dipakai oleh HTI mengindikasikan bendera tersebut memiliki kesamaan dengan acuannya. Dalam hal ini, acuan tersebut adalah bendera yang digunakan Nabi Muhammad. Dengan kata lain, al-ra>yah dan al-liwa> di HTI bernilai ikonis karena meniru bendera Rasulullah. Kendati al-ra>yah dan al-liwa> bersifat ikonik, terdapat pula perbedaan penggunaan antara yang dilakukan pada masa Nabi Muhammad dengan yang terjadi dalam tradisi HTI. Dalam peperangan semasa Nabi, al-liwa> hanya ada satu, sedangkan al-ra>yah dimungkinkan berjumlah banyak; saat itu, posisi al-liwa > berada di dekat pemimpin tertinggi, dan al-ra>yah digunakan tiap pemimpin divisi atau pempinan kabilah.

Selain sebagai simbol Islam, al-ra>yah dan al-liwa> di HTI juga menjadi simbol penegakan Khilafah. Dengan kata lain, bendera itu memiliki kapasitas untuk dikaitkan dengan ide penegakan Khilafah. Nilai simbolis al-ra>yah dan alliwa> terkait dengan penegakan Khilafah dikukuhkan dengan keberadaan bendera tersebut di tengah-tengah slogan HTI yang selalu terkait dengan Khilafah. Status al-ra>yah dan al-liwa> yang memiliki nilai simbolis terkait dengan negara Khilafah sekaligus dapat digunakan untuk memperjelas dua hal yang seakan-akan bertentangan, yaitu di satu sisi HTI tidak menggunakan kekerasan dan di sisi lain menggunakan atribut Rasulullah yang digunakan dalam peperangan. Kendati digunakan dalam peperangan, al-ra>yah dan alliwa> bukan simbol peperangan tapi simbol negara.

\section{Semiologi Roland Barthes}

Roland Barthes merupakan sosok penting dalam perkembangan ilmu semiologi. Barthes dikenal sebagai tokoh penerus dari tokoh strukturalis Ferdinad De Saussure dalam bidang semiologi. Roland Barthes lahir di Charboug 
pada tanggal 12 November $1915 .{ }^{26}$ la terlahir dari pasangan Louis Barthes, seorang perwira angkatan laut, dan Henriette Barthes,seorang Protestan yang taat. ${ }^{27}$ Dalam sejarah hidupnya, ia tidak pernah mengenal langsung sang ayah. Belum lagi usianya setahun, Barthes sudah ditinggalkan ayahnya ke medan pertampuran di laut Utara, dan meninggal di sana. Sepeninggal ayahnya, Barthes hijrah bersama ibu, bibi dan neneknya ke Bayonne. Di sana, Barthes mendapatkan kasih sayang yang sangat besar dari keluarganya, dan menghabiskan masa kanak-kanak sebelum diajak ibunya tinggal di Paris. Selama di Bayonne, Barthes mendapat pelajaran musik dan piano dari bibinya. . ${ }^{28}$

Karya-karya yang dihasilkan oleh Barthes diantaranya, ${ }^{29}$ Elementary of Semiology, S/Z, Mythologies, Camera Lucida dan beberapa karya esai lain seperti the death of author. Barthes Meninggal 26 Maret $1980.3^{30}$ Setelah sebelumnya dirawat karena ia tertabrak truk dan juga karena penyakit tuberculosis yang ia derita sejak lama. ${ }^{31}$

Kelahiran semiologi tak lepas dari dua tokoh yaitu Charles Sanders Pierce dan Ferdinand Saussure. Kedua tokoh tersebut hidup satu zaman namun tidak saling mengenal. Pierce yang memliki latar belakang ahli logika dan Saussure berlatar belekang linguistik. Pierce menggunakan istilah semiotika dan Saussure menggunakan istilah semiologi. Tidak ada perbedaan yang essensial terhadap kedua istilah ini, yang berbeda hanya

\footnotetext{
${ }^{26}$ David Herman, Roland Barthes, dalam Hans Berens and Joseph Natoli, Postmodernism: The Key Figure, (Massachusetts: Blackwell, 2002), 38

${ }^{27}$ Jonathan Culler, Barthes: A Very Short Introduction (New York: Oxford University Press, 1983 ), 8

${ }^{28} \mathrm{lbid}, 8$

${ }^{29}$ Lebih lengkapnya lihat : Louis Jean Calvet, Roland Barthes a Biography Trans by Sarah Wykes(. Indiana : Indiana University Press, 1990), 279- 281

30 Roland Barthes, Memebedah Mitos-Mitos Budaya Massa.( Yogyakarta; Jalasutra, 2010), XIII. Lihat pula : Louis Jean Calvet, Roland Barthes a Biography...,235

${ }^{31}$ Roland Barthes, The Grain of the Voice, Interview 1962-1980, trans. By Linda Coverdale, New York: Hill and Wang, 1985). 368
} 
mengacu pada orientasi pengguna istilah saja. Jika semiotika mengacu pada kubu Pierce dan maka semiologi mengacu pada kubu Saussure. ${ }^{32}$

Semiotika atau semiologi berasal dari bahasa Inggris semiotic sedangkan bahasa Yunani semeion yaitu tanda, yang berarti teori tanda-tanda. ${ }^{33}$ Mengkaji tanda-tanda untuk menemukan makna-makna yang ada dibaliknya. Menurut Saussure semiotika atau semiologi merupakan ilmu yang mengkaji tanda-tanda dalam kehidupan sosial. 34

Umberto Eco mengatakan Semiotika secara prinsipil ialah ilmu yang mengkaji segala sesuatu yang dapat digunakan untuk berbohongan. Atau kerapkali disebut dengan teori dusta. 35

\section{Penanda dan petanda}

Semiologi muncul sebagai pembacaan akan adanya penandaan dan petandaan yang disebut dengan tanda. Menurut Ferdinand De Saussure, sebuah tanda terdiri dari penanda (signifier) dan petanda (signified). ${ }^{36}$ Hubungan dan relasi antara penanda dan petanda bersifat arbiter karena tidak ada ketekaitan logis. Penandaan adalah proses yang terjadi di pikiran pada saat menggunakan atau menafsiri tanda. ${ }^{37}$

Penanda mengacu pada petanda yang kemudian mengacu pada referensi atau realitas. ${ }^{38}$ Penandaan yang bersifat arbiter mengacu pada ranah acuan yang tidak terbatas. Acuan dapat bersifat konkret, abstrak ataupun imajiner. Acuan itu mungkin ada, pernah ada atau mungkin akan ada di

\footnotetext{
32 Ibid, 2

33 Lorens Bagus, Kamus Filsafat.( Jakarta; Gramedia Pustaka Utama, 2000 ), 985.

34 Ferdinand De Saussure, Pengantar Linguistik Umum. Diterjemahkan; Rahayu S. Hidayat, ( Yogyakarta; Universitas Gajah Mada Press, 1988 ), 82

35 Umberto Eco, Teori Semiotika; Signifikasi komunikasi, Teori Kode, serta Teori Produksi- Tanda, ( Yogyakarta; Jalasutra, 2011), 7

36 Yasraf A Piliang, Hipersemiotika; Tafsir Cultural Studies Atas Matinya Makna. (Yogyakarta; Jalasutra, 2000 ),158

37 Marcel Danesi, Pesan, Tanda dan Makna; Buku Teks Dasar Mengenai Semiotik dan Teori Komunikasi. Diterjemahkan; Evi Setyarini dan Lusi Lian Piantari.( Yogyakarta; Jalasutra, 2012 ), 15 ${ }^{38}$ Yasraf A Piliang, Hipersemiotika; Tafsir Cultural Studies...., 158
} 
masa yang akan datang. Semua yang dibayangkan oleh manusia dapat menjadi sebuah acuan. 39

\section{Denotasi dan Konotasi}

Hubungan antara penenada dan petanda menghasilkan sebuah makna yang terbentuk dari konvensi sosial. Roland Barthes mengembangkan dua tingkat pertandaan (straggered systems), yang memungkinkan untuk dihasilkannya makna yang juga bertingkat-tingkat, yaitu tingkat denotasi (denotation) dan konotasi (connotation).

Denotasi adalah pertandaan yang menjalaskan hubungan antara penanda dan petanda atau antara tanda dan rujukanya pada realitas yang menghasilkan makna eksplesit. Denotasi adalah tanda yang memiliki tingkat konvensi atau kesepakatan yang tinggi.

Konotasi adalah sistem tanda tingkat kedua, di mana yang menjadi plane of expression-nya adalah sistem tanda tingkat pertama. Meskipun sistem tanda tingkat pertama berupa rangakain tanda, pada saat berubah posisi menjadi konotator, ia hanya memiliki signified tunggal. Karakter Signified dalam konotasi mesti umum, global dan menyebar. Barthes menyebutnya ideologi. Ideologi di sini mengacu pada gagasan Hjelmslev dimengerti sebagai bentuk (form) signified bagi konotatif, sementara rhetoric menjadi bentuk (form) bagi konotator. ${ }^{40}$

\section{Pemaknaan (Signification)}

Kata Signification berasal dari bahasa latin, significatio. Secara etimologis artinya hal menunjuk, hal menyatakan, pengungkapan, petunjuk. Dari beberapa arti ini, "hal menunjuk" adalah arti yang paling dekat dengan konsep signification yang akan dibahas oleh Barthes. Karena, arti ini berkaitan dengan peristiwa penandaan dari pada tanda itu sendiri. Barthes menandasakan bahwa "signification dipahami sebagai proses...sebuah tindakan memproduksi

\footnotetext{
39 Aart Van Zoes, Serba-Serbi Semiotika. Jakarta; Gramedia Pustaka Utama, 1991., 15

${ }^{40}$ Roland Barthes, Element of Semiology, (London: Jonathan cape, 1967), 90 - 91
} 
tanda". ${ }^{41}$ Signification penting mendapat perhatian karena pada saat kita berhadapan dengan tanda, kita sudah selalu dibayang-bayangi oleh makna. Oleh karena itu signification di sini dilihat sebagai keseluruhan sistem.

\section{Mitos}

Dalam kerangka Barthes, konotasi identik dengan operasi ideologi, yang disebutnya sebagai mitos dan berfungsi untuk mengungkapkan dan memberikan pembenaran bagi nilai-nilai dominan yang berlaku dalam suatu periode tertentu. Di dalam mitos juga terdapat pola tiga dimensi penanda, petanda, dan tanda. Mitos adalah suatu sistem yang janggal karena ia dibentuk dari rantai semiologis yang telah eksis sebelum pola tiga dimensi: penanda, petanda dan tanda. Mitos merupakan sistem semiologis tatanan kedua. ${ }^{42}$

Penanda mitos menampilkan diri secara ambigu: ia merupakan makna dan bentuk, penuh pada satu sisi dan kosong di sisi lain. ${ }^{43}$ Yang dibongkar Barthes tidak hanya relasi dan tingkat pertandaan akan tetapi konsep ideologi itu sendiri. Pemaknaan pada tingkat kedua dalam menyusuri makna dibalik tanda berkaitan erat dengan konteks budaya.

Ideologi yang dimaksud sebagai tingkat kedua pertandaan adalah sistem, gagasan, ide atau kepercayaan yang menjadi konvensi mapan dalam satu masyarakat yang mengartikulasikan dirinya pada sistem representasi atau sistem pertandaan. ${ }^{44}$

Contoh mitos yang dikemukan Barthes adalah gambar serdadu kulit hitam yang memberi hormat pada tricolor (bendera Prancis yang memiliki tiga warna) di majalah Paris-Match. Sebagai sistem semiotika tingkat pertama, gambar tersebut sebagai sign terdiri dari signifier (foto serdadu yang memberi hormat pada bendera Perancis) dan signified (serdadu "sungguhan" yang memberi hormat pada bendera Perancis). Foto ini bagi Barthes, orang yang memang lahir

\footnotetext{
${ }^{41}$ Roland Barthes, Element of Semiology, 48

${ }^{42}$ Roland Barthes, Memebedah Mitos-Mitos.., 169

43 Ibid, 307

44 Yasraf A Piliang, Hipersemiotika; Tafsir Cultural Studies..., 167
} 
di Perancis, sudah kosong akan makna denotatifnya. Gambar sedadu itu malah menunjukan kebesaran Perancis. "Kebesaran Perancis" dihasilkan dari sistem semiotika yang berpijak pada sistem tanda tingkat pertama. Rumusannya demikian: form (foto serdadu Negro yang menghorat bendera Prancis), concept (kebesaran imperium Perancis) dan signification (kebesaran Perancis yang tidak membeda-bedakan warna kulit). 45

\section{Analisis semiologi Roland Barthes terhadap Al-Ra>yah dan Al-Liwa>}

Seperti yang dijelaskan di atas, semiologi merupakan ilmu tantang "tanda". Sedangkan tanda erat kaitannya dengan simbol. Pengetahuan manusia bukan hanya dihasilkan oleh pengalaman indrawi, tetapi juga oleh hasil reflektif yang pikiran. Pengetahuan akan sulit dikenal banyak khalayak jika ia bersifat abstrak. Namun menjadi mudah jika ekspresi pikiran itu diungkapkan dalam simbol; suatu kategori "tanda" (signs) tetapi bukan "isyarat” (signals)46. Hal ini yang membedakan manusia dengan binatang. Manusia mempunyai intelegensia-simbolis dan imajinasi-simbolis. Dalam taraf binatang, memang ada yang disebut dengan "tanda”, tetapi bukan sign, melainkan signals. Anjing Pavlov misalnya, bukan menerima dan patuh terhadap simbol yang diberikan, tetapi menerima dan patuh terhadap tanda atau isyarat yang diberikan. Tanda belumlah mencapai taraf sekompleks dan serumit simbol. Tanda bila dilepaskan dari konteks menjadi tidak berarti. Seorang wasit sepak bola meniup peluit panjang tanda pertandingan berakhir. Namun jika itu dilakukan di luar konteks pertandingan sepak bola, menjadi tidak berarti. Tidak demikian dengan simbol. Simbol sangat kompleks dan rumit, karena melalui simbol seolah manusia tidak lagi berhadapan dengan realitas. Realitas fisik tertarik ke belakang, dan manusia melangkah maju bersama dengan simbol-simbol yang dimilikinya, masuk ke kedalaman tanpa batas, seolah menembus ruang dan waktu. Manusia tidak lagi menggeluti "benda pada dirinya sendiri", tetapi

45 Roland Barthes, Mytholgies, trans. Jonathan Cope, (New Yok: Hilland Wang, 1972), 116

46 J.van Baal \& W.E.A. van Beek, Symbols for Communications ( Van Gorcum:Assen, 1985), 151 
menyelimuti diri dengan pralambang, citra-citra, atau makna yang diungkapkan dalam simbol. Benda pada dirinya sendiri seolah lenyap dan diganti dengan "benda simbolis".

Kembali pada semiologi, dikemukakan oleh Roland Barthes, yaitu distingsi signified dan signifier. Kedua distingsi tersebut mempunyai makna yang berbeda dalam penggunaannya. Signified mempunyai makna yaitu petanda dan signifier mempunyai makna penanda. ${ }^{47}$ Fungsi dari penanda adalah menjelaskan tentang makna dari aspek warna, garis, gambar dari suatu simbol tersebut, sedangkan petanda mempunyai fungsi untuk menjelaskan makna dari aspek warna, garis, dan gambar dari suatu simbol yang ada. Dengan menggunakan kedua distingsi tersebut maka peneliti ingin membedah atau menafsirkan simbolisasi keagamaan dari organisasi HTI atau HT yang tidak lain adalah bendera al-ra>yah dan al-liwa>..

Berangkat dari apakah bendera yang dibakar adalah bendera HTI atau bukan, maka peneliti ingin menyimpulkan dengan menggunakan pisau analisis semiologis Roland Barthes dalam membahas bendera HTI sebagai simbol keagamaan mereka. Menurut sistem dari distingsi signified dan signifier dalam melihat permasalahan bendera HTI. Maka tiga gambaran yang bisa peneliti ambil yaitu pertama tanda dalam HTI adalah bendera al-ra>yah dan alliwa> sebagai tanda dan simbol bagi pergerakan mereka, kedua penandanya adalah kalimat tauhid, dan warna bendera, ketiga adalah makna dari kalimat tauhid, dan warna bendera.

Selanjutnya, dari distingsi signified dan signifier,kita bisa menggali terdapat makna denotasi dari al-ra>yah dan al-liwa>. Dalam menggali makna denotasi, Barthes mengusahakannya dari segi bahasa, bagi Barthes bahasa adalah sebuah sistem tanda yang mencerminkan asumsi-asumsi dari suatu

\footnotetext{
47 Asep Ahmad Hidayat, Filsafat Bahasa Mengungkap Hakikat Bahasa dan Tanda (Bandung: Remaja Rosdakarya, 2006), 110.
} 
masyarakat tertentu dalam waktu tertentu. ${ }^{48}$ Dalam setiap eseinya, Barthes menghabiskan waktu untuk menguraikan dan menunjukkan bahwa konotasi yang terkandung dalam mitologi-mitologi tersebut biasanya merupakan hasil konstruksi yang cermat dan berbeda dari satu masa ke masa yang lain.

Makna denotasi dari al-ra>yah dan al-liwa> berdasarkan pemahaman HTI yang cendrung tekstualis, didapatkan berdasarkan pencarian makna dari hadits ibn Abbas di atas, untuk kemudian mereka adopsi dengan dalih iqtida>' dan mengikuti Sunnah tanpa memperhatikan teks dan konteks. Dari pemahaman itu, mereka mencoba untuk memvisualisasikan dalam bentuk gambar yang telah beredar dimana-mana. Adapun visualisasi nya sebagai berikut :

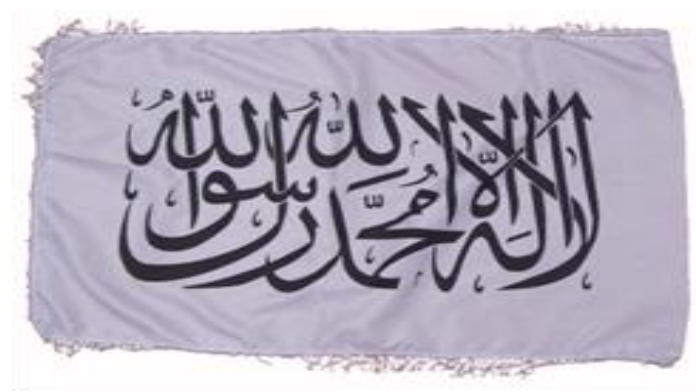

Foto Deni Junaidi 2011

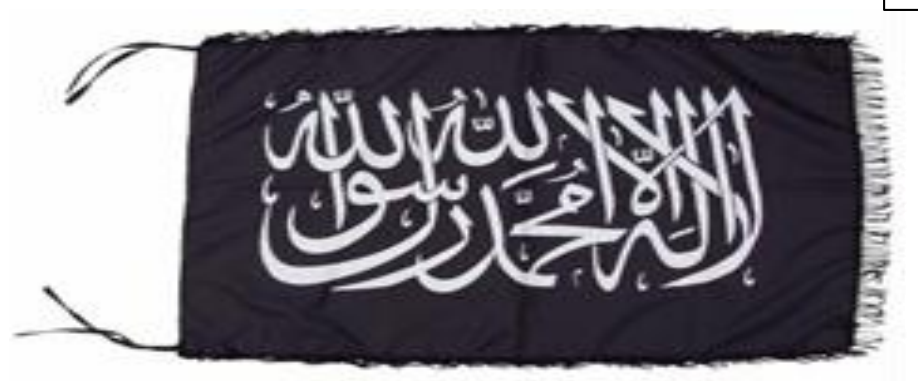

Ketika terjadinya insiden pembakaran bendera tauhid, oknum pembakar menganggap bendera yang dibakar identik dengan idiologi HTI. Organisasi yang secara resmi dianggap ilegal oleh pemerintah. Pemahaman yang demikian bisa dijelaskan dengan tinjuan semiologi Roland Barthes.

48 Roland Barthes, Pertualangan Semiologi, ed Dr. Wening Udasmoro ( Yogyakarta : Pustaka Pelajar, 2007 ), 29 
Di dalam alam pemikiran seseorang yang mengklaim visualisasi bendera di atas adalah bendera HTI, terjadi perubahan makna dari denotatif kepada konotatif. Makna konotatif dari bendera di atas adalah Khila>fah Isla>miyah. Pemaknaan demikian timbul dari perjalanan sejarah dan kebudayaan yang panjang.

Untuk lebih jelas mengetahui kronologi, bisa kita amati tabel semiologi Roland Barthes di bawah ini :

\begin{tabular}{|l|l|}
\hline Teks dan Visual & $\begin{array}{l}\text { Hadits yang menyatakan bahwa al-ra>yah } \\
\text { Rasulullah SAW berwarna hitam dan al-liwa }>- \\
\text { nya berwarna putih, tertulis di dalamnya } \\
\text { la>ila>h illa> Alla>h Muh\{ammad rasu>l Alla>h }\end{array}$ \\
\hline Denotatif & $\begin{array}{l}\text { Di dalam menerapkan ajaran Islam haruslah } \\
\text { secara kaffa<h, termasuk dalam hal bendera, } \\
\text { harus sesuai dengan yang diterapkan oleh } \\
\text { Rasulullah baik secara warna dan bentuk. }\end{array}$ \\
\hline Konotatif & $\begin{array}{l}\text { Dalam konteks kekinian, bendera dengan } \\
\text { visualisasi makna denotatif di atas, menjurus } \\
\text { pada penegakan khila<fah yang berorientasi } \\
\text { pada organisasi tertentu }\end{array}$ \\
\hline Mitos & $\begin{array}{l}\text { Simbol al-ra>yah dan al-liwa> pada masa kini } \\
\text { menjadi legalitas pembeda antara hukum } \\
\text { Islam dan T\{oghut, antara Khila<fah dan } \\
\text { Skuler. Simbolisasi ini menjadi trend dan } \\
\text { fashion di kalangan organisasi yang } \\
\text { mendambakan sistem Khila<fah. }\end{array}$ \\
\hline
\end{tabular}

Dalam perjalanannya, semiosis al-ra>yah dan al-liwa> dapat dipahami dengan mempertimbangkan konteksnya. Konteks bendera itu meliputi konteks waktu maupun konteks ruang. Konteks waktu adalah sejarah 
bendera tersebut, dan konteks ruang merupakan budaya tempat keberadaannya, yaitu budaya HTI.

Dalam konteks waktu terlihat, al-ra>yah dan al-liwa> sebagai sebuah simbol pertama kali digunakan oleh Nabi Muhammad setelah mendirikan negara Islam di Madinah pada tahun 622. Al-liwa> atau bendera Rasulullah memiliki ground putih dan charge kalimat sahadat, sedangkan ground al-ra>yah atau panji adalah hitam. Fungsi keduanya bukan lah sebagai simbol negara Islam, lebih sering dipakai dalam peperangan. Setelah Nabi wafat pada tahun 632, empat orang sahabatnya, Abu Bakar, Umar, Usman, dan Ali, yang disebut periode Khulafaur Rasyidin, memakai panji hitam yang pernah digunakan pada masa Nabi.

Secara visual, terdapat juga perbedaan khat\{ dalam al-liwa> dan alra>yah yang digunakan HTI dengan yang digunakan Nabi Muhammad. Pada zaman Rasul Khat\{ yang masih sederhana, yaitu makki-madani. Sedangkan dalam bendera HTI yang digunakan yaitu khat\{ thuluth. Padahal khat thuluth belum dikenal pada zaman Nabi Muhammad, saat itu khat yang ada masih sederhana. Khat thuluth diciptakan setelah Nabi Muhammad wafat. Bentuk khat $\{$ thuluth tidak dapat dilepaskan dari kodifikasi yang dilakukan Ibnu Muqlah, asisten Khalifah Bani Abasiyah yang lahir pada akhir abad ke-9.49

Ibrahim as-Syajari yang lebih awal merintis Khat thuluth juga hidup di masa Bani Abbas.50 Demikian juga, Qubah al-Muharris yang disebut- sebut menciptakan Khat thuluth hidup pada masa Khilafah Umawiyah. ${ }^{51}$

Dengan demikian visualisasi al-ra>yah dan al-liwa> dengan versi yang beredar dengan khat thuluth bukanlah bendera Rasul yang ada di zaman beliau.

\footnotetext{
49 Sirojudddin AR D, Seni Kaligrafi Islam. Jakarta: Multi Kreasi, cetakan ke-4,1992 86-93. ${ }^{50}$ Sirojuddin AR D, Koleksi Karya Master Kaligrafi Islam (Naskhi, Sulus, Diwani, Diwani Jali, Farisi, Kufi, Riq'ah). Jakarta: Darul Ulum Press, 2007.70.

${ }^{51}$ Hamin Yasin Safadi, Kaligrafi Islam, terj. Abdul Hadi W.M. Jakarta: Pantja Simpati, 1986. 16
} 
Kembali kepada makna konotasi, setelah konotasi menetap dalam jangka waktu yang lama, maka mitos pun akan terjadi. Visualisasi yang tampak pada al-ra>yah dan al-liwa> sudah menjadi mitos bahkan sudah mengarah kepada idiologi tertentu.

Disini bisa ditemukan garis pemicu konflik pada insiden pembakaran bendera. BANSER memahami bahwa bendera berlafal tauhid yang dibakar adalah bendera identitas HTI, hal itu merupakan proses panjang dari denotatif, konotatif, mitos, bahkan ideologi. Dengan kata lain, bendera berlafal tauhid yang dibakar, merupakan pemahaman dari makna konotatif atas al-ra>yah dan al-liwa> yang menunjukkan idologi tertentu. Sedang bagi HTI bendera yang dibakar adalah panji Rasul yang memiliki makna denotatif. HTI hanya mencukupkan diri hanya pada tataran makna denotatif versi mereka.

\section{PENUTUP}

Pada penghujung pembahasan jurnal ini, berdasarkan apa yang telah dibahas sebelumnya, peneliti bisa menarik beberapa kesimpulan sebagai berikut:

1. Titik pemicu terjadinya konflik pembakaran bendera berlafad tauhid terletak pada tarik ulur klaim apakah al-ra>yah dan al-liwa> merupakan bendera dan panji Rasulullah ataukah kedua-duanya merujuk pada suatu ideologi kelompok tertentu?

2. Perbedaan klaim tersebut muncul salah satunya disinyalir dari cara baca yang berbeda terhadap tanda-tanda yang ada dalam al-ra>yah dan al-liwa>. Tanda-tanda yang dimaksud bisa berupa teks maupun non-teks.

3. Dalam dakwahnya, HTI menggunakan al-ra>yah dan al-liwa> sebagai simbol pergerakannya. Mereka mengklaim simbol yang mereka pakai murni dari Rasululah. Meskipun kalau kita amati ada perbedaaan yang sangat signifikan antara panji Rasul dan bendera simbol HTI dari sisi fungsi dan khat yang dipakai. 
4. Dari sisi analisis semiologi, dalam tragedi pembakaran bendera berlafal tauhid, oknum BANSER pembakar bendera memahami bahwa bendera berlafal tauhid atau al-ra>yah dan al-liwa> yang dibakar adalah bendera identitas HTI, hal itu merupakan proses panjang dari denotatif, konotatif, mitos, bahkan ideologi. Dengan kata lain, bendera berlafal tauhid atau al-ra>yah dan al-liwa> yang dibakar, merupakan pemahaman dari makna konotatif atas al-ra>yah dan al-liwa> yang menunjukkan idologi khilafah HTI Sedangkan bagi HTI, bendera yang dibakar adalah panji Rasul yang memiliki makna denotatif. HTI mengklaim bendera yang dibakar adalah panji Rasulullah. HTI hanya mencukupkan diri hanya pada tataran makna denotatif versi mereka.

\section{REFERENSI}

Abu Dawud al- Sijistani, Sulayman bin al-Ash'ath bin Ishaq bin Bashir bin Shaddad bin 'Amr al-Azdi Sunan Abi Dawud, Muhaqqiq: Muhammad Muhy al-Din 'Abd al-Hamid, Vol. 3 .Beirut: al-Maktabah al-'Asriyyah, tt.

AR D,Sirojuddin. Koleksi Karya Master Kaligrafi Islam (Naskhi, Sulus, Diwani, Diwani Jali, Farisi, Kufi, Riq'ah). Jakarta: Darul Ulum Press, 2007. . Seni Kaligrafi Islam. Jakarta: Multi Kreasi, cetakan ke-4,1992

Baal, J.van \& W.E.A. van Bee., Symbols for Communications.Van Gorcum:Assen, 1985 .

Bagus, Lorens. Kamus Filsafat. Jakarta; Gramedia Pustaka Utama, 2000.

Barthes, Roland.Memebedah Mitos-Mitos Budaya Massa. Yogyakarta; Jalasutra, 2010.

. Mytholgies, trans. Jonathan Cope. New Yok: Hilland Wang, 1972. . Element of Semiology. London: Jonathan cape, 1967. . The Grain of the Voice, Interview 1962-1980, trans. By Linda Coverdale, New York: Hill and Wang, 1985 
Pertualangan Semiologi, ed Dr. Wening Udasmoro. Yogyakarta : Pustaka Pelajar, 2007.

Calvet,Louis Jean. Roland Barthes a Biography Trans by Sarah Wykes. Indiana : Indiana University Press, 1990.

Culler, Jonathan .Barthes : A Very Short Introduction .New York : Oxford University Press , 1983.

Darwis, M. (2016). Teologi Dakwah Dalam Kajian Paradigmatik. Dakwatuna: Jurnal Dakwah dan Komunikasi Islam, 2(1), 85-106.

Darwis, M. (2019). Rejuvenasi Paradigma Dakwah Di Era 4.o. Dakwatuna: Jurnal Dakwah dan Komunikasi Islam, 5(1), 58-67.

Eco, Umberto. Teori Semiotika; Signifikasi komunikasi, Teori Kode, serta Teori Produksi-Tanda,.Yogyakarta; Jalasutra, 2011.

Herman, David. Roland Barthes, dalam Hans Berens and Joseph Natoli, Postmodernism: The Key Figure, .Massachusetts: Blackwell, 2002.

Hidayat, Asep Ahmad. Filsafat Bahasa Mengungkap Hakikat Bahasa dan Tanda.Bandung: Remaja Rosdakarya, 2006.

Hujaili ( al) ,Abdullah bin Muhammad bin Sa'ad .Al-‘Alamu al-Nabawiy al-Shari<f wa Tat\}bi<qotuhu< al-Qodi<matu wal Mu'as\{orotu .Madinah alMunawarah: Maktabatah al-`Ulu<m wa al-H\{ikam , 2002.

Ibn Hisyam al-Muafiri,Abu Muhammad Abdul Malik .Si>rah Nabawi<yah Ibnu Hisha<m, Jilid 2, Terj. Fadhli Bahri .Jakarta: Darul Falah, cetakan ke-7, 2008

Ibn Ma>jah, 'Abd Allah Muhammad bin Yazi>d al-Quzwayni, Sunan Ibn Ma>jah, Muhaqqiq: Muhammad Fu'ad 'Abd al-Baqi, vol. 2, .tk: Dar Ihya' al-Kutub al-‘Arabiyyah, tt.

Junaedi, Deni . "Bendera di Hizbut Tahrir Indonesia Daerah Istimewa Yogyakarta (Kajian Konteks Sejarah, Konteks Budaya, dan Estetika Semiotis)", Tesis, Universitas Gadjah Mada, Yogyakarta, 2012 
Piliang, A Yasraf.. Hipersemiotika; Tafsir Cultural Studies Atas Matinya Makna. Yogyakarta; Jalasutra, 2000.

Podeh, Elie "The Symbolism of the Arab Flag in Modern Arab States: Between Commonality and Uniqueness", Nations and Nationalism, Hebrew University of Jerussalem, 17 (2), 2011.

Pusat Bahasa Departemen Pendidikan Nasional, Kamus Bahasa Indonesia .Jakarta: Pusat bahasa, 2008.

Rachman, Ibnu ."Simbolisme Agama dalam Politik Islam", Jurnal Filsafat, Vol. 33, No. 1, April, 2003.

Rachman, R. F. (2015). Representasi Muslim Dalam Film-Film Produksi Hollywood (Analisis Dua Film Kathryn Bigelow: The Hurt Locker Dan Zero Dark Thirty) (Master Thesis, Universitas Airlangga).

Rachman, R. F. (2016). Representasi Islam Di Film Amerika Serikat. Dakwatuna: Jurnal Dakwah dan Komunikasi Islam, 2(2), 1-12.

Safadi, Hamin Yasin. Kaligrafi Islam, terj. Abdul Hadi W.M. Jakarta: Pantja Simpati, 1986.

Saliba, Jhon A. 'Homo Religiosus' in Mircea Elinde. E. J. Brill : Leiden, 1976.

Saussure, Ferdinand De. Pengantar Linguistik Umum. Diterjemahkan; Rahayu S. Hidayat, Yogyakarta; Universitas Gajah Mada Press, 1988.

Subahri, B. (2018). Pesan Simbolik Tradisi Sandingan Pada Masyarakat Pandalungan Di Desa Jenggrong Kecamatan Ranuyoso Kabupaten Lumajang. Dakwatuna: Jurnal Dakwah dan Komunikasi Islam, 4(2), 292305 .

Subahri, B. (2020). Pesan Semiotik Pada Tradisi Makan Tabheg Di Pondok Pesantren. Dakwatuna: Jurnal Dakwah dan Komunikasi Islam, 6(01), 88103.

Tirmidhi> ( al ),Muhammad bin 'Isa bin Sawrah bin Mu>sa. Sunan al-Tirmidhi, Muhaqqiq: Bashar'Iwad Ma'ruf, vol. 4 .Beirut: Da>r al-Gharb al-Islami>, 1998. 
Zoes, Aart Van. Serba-Serbi Semiotika. Jakarta; Gramedia Pustaka Utama, 1991.

\section{Internet}

“Bagaimana pembakaran 'bendera HTI' itu jadi 'pembakaran bendera tauhid'? dalam :https://www.bbc.com/indonesia/indonesia-45951832

"Ismail Yustanto: yang dibakar banser bukan bendera HTI" dalam https://news.detik.com/berita/d-4269180/ismail-yusanto-yang-dibakarbanser-bukan-bendera-hti

“Respon pembakaran bendera kader PDIP merahkan Surabaya” dalam tulisan https://www.cnnindonesia.com/nasional/20200629181108-20518752/respons-pembakaran-bendera-kader-pdip-merahkan-surabaya

Hosen, Nadirsyah. "penjelasan soal hadits nabi dan bendera HTI" dalam tulisan https://nadirhosen.net/kehidupan/negara/penjelasan-soal-hadits-nabidan-bendera-khilafah-hti-isis 